\title{
Implementation of Small Sided Game in Improving Aerobic Capacity of Futsal Women Players at STKIP Muhammadiyah Kuningan
}

\author{
Ribut Wahidi1 ${ }^{*}$, Intan Aprilia Utami², Oman Hadiana ${ }^{3}$, Firman \\ Adityatama $^{4}$
}

$1 * 234$ STKIP Muhammadiyah Kuningan, Indonesia

\author{
Article History: \\ Received: 1 April 2021 \\ Accepted: 26 April 2021 \\ Published: 26 April 2021
}

Keywords:

Small Sided Game; Aerobic;

Futsal

\begin{abstract}
The purpose of this study was to determine the effect of small sided game training on aerobic capacity in futsal. This research method is an experimental method with a one-group pretestposttest design research. The sample used is 12 futsal players in the Women's Futsal UKM STKIP Muhammadiyah Kuningan. The instrument used in this study was the bleep test. Data analysis techniques in this study using prerequisite test analysis and hypothesis testing. The results obtained by researchers from the results of the calculation of the $T$ test paired sample test explained that there is a significant difference in the effect of the aerobic capacity level using the small sided game method.
\end{abstract}

\section{How To Cite:}

Wahidi, R, Utami, I, A, Hadiana, 0, \& Adityatama, F. (2021). Implementation of Small Sided Game in Improving Aerobic Capacity of Futsal Women Players at STKIP Muhammadiyah Kuningan. Indonesian Journal of Sport Management, 1(1), 58-64

Corresponding author: Ribut Wahidi, STKIP Muhammadiyah Kuningan, West Java, Indonesia

Email: ributwahidi37@upmk.ac.id 


\section{INTRODUCTION}

Meanwhile, 81.8\% suggested that futsal can develop multifunctional players and is important to soccer. However, data show coaches' perceptions were weaker for rules which differ strongly to soccer, such as the fly keeper rule and no off-sides in futsal. Only $54.6 \%$ felt that the fly keeper rule was very important or important to soccer talent development (Yiannaki, et. al., 2018). The tactical structure of such a sport as futsal is a complex one. The great physical and tactical burden of this sport encourages the study of the principles of offensive and defensive play (Agras, et. al., 2016).

The futsal game requires players to always make movements during the game, these movements are carried out continuously and repeatedly. Performing movements with such intensity clearly requires good physical condition (Owen, et al., 2004). In the futsal game, aerobic endurance abilities or high VO2 max are prioritized. V02max is the ability of the human respiratory organs to breathe as much oxygen as possible during exercise (Sukadiyanto, 2011). Endurance is the ability to fight fatigue during sports or work activities for a long time (Sukadiyanto, 2011). After doing well-programmed physical exercises, the results of these physical exercises can be seen from the increasing appearance of a player which ultimately has a positive impact on team performance (Lhaksana, 2011). One form of resistance training is the small sided game.

The small-sided games (SSG) are being suggested as an excellent practice-tool to stress out the players' decision-making and move towards a better understanding of tactical performance (Davids, et. al., 2013; Gonçalves, et. al., 2016). SSCGs are commonly considered as modified games played on reduced pitch dimensions (small-sided), often using adapted rules and involving a smaller number of players than traditional games (representing manipulations of playing conditions) (Dellal et al., 2008; Gabbett, et. al., 2009; Hill-Haas, et. al., 2011; Vilar, et. al., 2014).

Small-sided games are very popular not only in adult soccer players but also in young players and their use begins from an early age. Due to the smaller pitch and the less number of participants during small-sided games, each player comes into contact with the ball and deals with common game situations more often (Capranica et al., 2001). Which means that small sided games are very popular not only in adult soccer players but also among young players and their use starts at an early age. Due to the smaller pitch and the fewer number of participants during small matches, each player is in contact with the ball and more frequently faces common game situations (Capranica et al., 2001).

The use of small sided games and game conditioning is widely suggested as an efficient strategy to increase certain practice times for players (Duarte et al., 2009). And, furthermore according to Katis and Kellis (2009) states that small sided games are mainly used for endurance and improvement of physical conditions, the effectiveness of small-sided games as conditioning stimuli needs to be optimized to allow players to compete at the highest level.

Small-sided games can be modified by changing factors such as the number of players, the size of the field, the rules of the game, and training encouragement (Aguiar, et al., 2012). Kristono (Jonni, 2003) "aerobics is an exercise that aims to improve the ability of the lungs, heart and blood circulation, where oxygen is the main factor in generating energy in body cells". Jamil (1998) gives the term "aerobic 
to live with air", which means a variety of physical exercises that can spur heart and lung activity for a long enough time to cause beneficial changes to the body. And, furthermore according to Irawan (1996) also states the notion of aerobics, namely "a type of exercise that uses a lot of oxygen, and uses a lot of energy such as carbohydrates and fats. Based on the description above, it can be concluded that aerobics is a type of exercise that uses a lot of oxygen, or exercises to increase oxygen. And aerobic exercise aims to improve the ability of the lungs, heart and blood circulation, the main factor is for energy generation.

Small sided games training is a form of training that modifies the game with restrictions, including restrictions on the number of players, field size, and length of play (Hadi et al., 2004). And furthermore, according to Wisesa et al., (2013) small side games training can also have an effect on increasing aerobic fitness because players can adapt to the environment they face and develop mental and physical technical skills to achieve maximum performance. The priority of small sided games training is to develop technical skills, tactics, mental and physical conditions of players (Rapids, 2010). The main findings of research conducted by (Dellal et al., 2011) state that by changing the number of touches on the ball instructed in smallsided games, the coach can manipulate the physical and technical demands in the game. Available studies show that physiological responses (e. g. heart rate, blood lactate concentration and perceived activity rating), tactical and technical skill requirements can be modified during small-sided games by changing factors such as number of players, field size, rules of play, and train encouragement (Aguiar, et al., 2012). From the above understanding, it can be concluded that the small sided game is a small game because it reduces the number of players and the size of the field so that the player's physical, technical and technical skills can increase.

\section{METHOD}

The method used in this research is the experimental method. According to Arikunto (2013), "Experiments are a way to find a causal relationship between two factors that are deliberately caused by researchers by reducing or setting aside disturbing factors. Experiments are always carried out with the intention of examining the consequences of a treatment. This research includes pre-experimentation. The experimental method is defined as a systematic method for building relationships that contain causal-effect relationships (Sukardi, 2015). The design used in this study is "The One Group Pretest Posttest Design" or the absence of a control group (Sukardi, 2015) while the design can be described as follows:

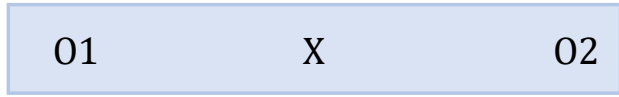

Figure 1. Pre-ekperimental Deign (One Group Pretest-Postest)

According to Sugiono (2015: 118) the sample is part of the number and characteristics possessed by the population the sample taken must be truly representative. The research sample used was a sample of 12 players. The sampling technique used was saturated sampling by determining the population to be the research sample in order to obtain 12 players. Sugiyono (2015: 148) states that "a 
research instrument is a tool used to measure observed natural and social phenomena". The instrument that will be used for this research is the bleep test: Iztok Kavcic1 et al. (2012) "The multi-stage $20 \mathrm{~m}$ shuttle run test or also known as the bleep test is a popular field test used to find the estimated V02max value. The V02max value data is used as an evaluation for athletes, both in evaluation in training and as a parameter of training achievement.

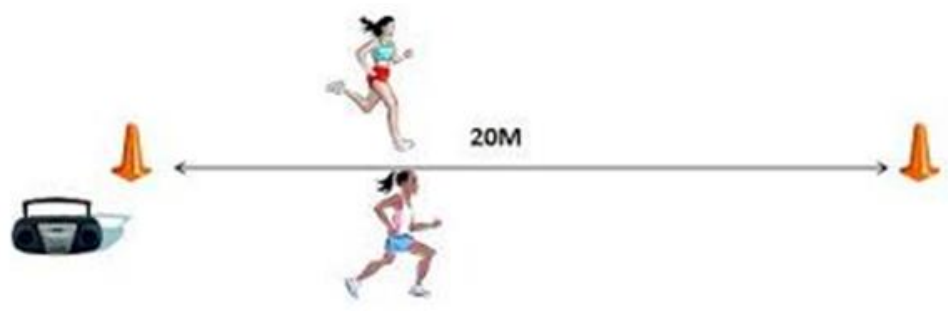

Figure 2. Bleep Test

Then before testing the hypothesis, it is necessary to do a prerequisite test. Testing the measurement results data related to the results of the researchers aims to help the analysis to be better. For this reason, this study will test the normality and homogeneity of the data. The decision to accept or reject the hypothesis at the $5 \%$ significance level to analyze the data using parametric statistics is used with the help of a computer program IBM SPSS statistics 25.

\section{RESULT AND DISCUSSION}

Based on the results of the prerequisite test with the normality test the data is normally distributed and the homogeneity test has homogeneous data. So that the hypothesis testing in this study uses the Paired Samples T Test. The data from the calculation results can be seen in the table below.

Data collected in tables / figures must be accompanied by narrative text and presented in a form that is easy to understand. Do not repeat at length the data that has been presented in tables and figures. Complete the existing table / figure by writing the source below each table/figure in 10 size. Here's an example table and figure:

Table 1. Paired Samples Test Results

\begin{tabular}{|c|c|c|c|c|c|c|c|c|}
\hline & \multicolumn{5}{|c|}{ Paired Differences } & $\mathrm{t}$ & Df & $\begin{array}{l}\text { Sig. (2- } \\
\text { tailed) }\end{array}$ \\
\hline & \multirow{2}{*}{ Mean } & \multirow{2}{*}{$\begin{array}{c}\text { Std. } \\
\text { Deviation }\end{array}$} & \multirow{2}{*}{$\begin{array}{l}\text { Std. } \\
\text { Error } \\
\text { Mean }\end{array}$} & $\begin{array}{l}95 \% \text { Cor } \\
\text { Interva } \\
\text { Differ }\end{array}$ & $\begin{array}{l}\text { fidence } \\
\text { of the } \\
\text { ence }\end{array}$ & & & \\
\hline & & & & Lower & Upper & & & \\
\hline $\begin{array}{cl}\text { Pair } & \text { pretest - } \\
1 & \text { posttest }\end{array}$ & -14.53288 & 7.67970 & 2.21694 & $19.41233^{-}$ & -9.65344 & -6.555 & 11 & .000 \\
\hline
\end{tabular}


Based on the results of the calculation of the table above, it is known that the Sig. (2-tailed) is $0.000<0.05$, then Ha is accepted and $\mathrm{HO}$ is rejected. This means that there is a significant difference in the effect of the level of aerobic capacity using the small-sided game method in futsal sports at women's Futsal UKM at STKIP Muhammadiyah, Kuningan. Several training innovations need to be developed in order to achieve a better performance quality. However, it is not certain what training innovations are most suitable for the characteristics of a field of science, especially for physical training for female futsal players. Because physical training has several forms of exercise that can be developed and must be improved. Therefore, it is necessary to conduct a study to determine whether an application of small side games can have an impact on aerobic capacity in futsal players, in this case, namely increasing aerobic endurance which is one of the most important things to support playing performance.

In this study, a small side game training method was applied to increase the aerobic capacity of futsal players. Another thing that is the finding of this study is that the small sided games pattern is an application of the special and specific principles of sports training, because the small sided games pattern in the study applies the principles of physical training using ball media as needed in soccer match conditions. Therefore, the results of this study reinforce the theory that to achieve maximum performance one must apply the principles of training properly, in this case the principles of specialization and training specifics. In addition to this, the findings found that players were more enthusiastic in doing physical training through the pattern of small sided games, this was because players could improve the quality of work in situations such as real games. As well as with the pattern of small sided games through training methods, besides being able to improve the quality of physical conditions, especially in terms of anaerobic capacity, the sample group also experienced an increase in ball possession during the actual game, this was seen in several friendly matches that were carried out after the final test of this research.

There is evidence that small-sided games (SSGs) are an effective training modality used for soccer-specific aerobic endurance (Balsom, 1999; Bangsbo, 2003). This kind of specific training can lead to adequate exercise intensity for improving both soccer-specific skills and generic aerobic fitness such as maximal oxygen uptake (VO2max) and anaerobic thresholds (Hill-Haas, Rowsell, Coutts, \& Dawson, 2008; Impellizzeri et al., 2006; Rampinini et al., 2007; Halouani, et. al., 2014).

To illustrate this, there are some differences between studies about the inclusion of goalkeepers and scoring without goalkeepers (Dellal et al., 2008; Mallo \& Navarro, 2008). In this context, Dellal et al. (2008) found that the 8 vs. 8 SSG with goalkeepers showed a $12 \%$ increase in the heart rate (HR) response expressed in percentage of heart rate reserve compared to the same game without goalkeepers. However, other studies reported a reduction in HR when the goalkeepers were included (Mallo \& Navarro, 2008; Sassi, Reilly, \& Impellizzeri, 2004; Halouani, et. al., 2014). 


\section{CONCLUSION}

In the Small Side Games pattern training, the condition is that they have a fairly good fitness ability, so that in practice the player does not feel heavy. Because the implementation of the Small Side Games training pattern has an impact on increasing average fitness and anaerobic capacity, it is recommended that futsal coaches be able to design specific training programs regarding the varied Small Side Games patterns because it is very important so that training needs become more meaningful and precise. on the training target. Adequate application of training by paying attention to training methods, training patterns, training principles, and training norms appropriately is an important key to getting a player's peak performance. For further research it is suggested that scientific development in coaching methods is more effective and efficient, so in this study it can be developed through other studies or application to other groups such as gender, age group, sports level (at the level of coaching or the professional level).

\section{ACKNOWLEDGEMENT}

Thank you to the STKIP Muhammadiyah students, especially the female futsal players who had the pleasure to help in completing this research.

\section{REFERENCES}

Agras, H., Ferragut, C \& Abraldes, J. A. (2016). Match Analysis in Futsal: A Systematic Review. International Journal of Performance Analysis in Sport, 16(2), 652-686. http://dx.doi.org/10.1080/24748668.2016.11868915

Aguiar, M., Botelho, G., Lago, C., MaçAs, V., \& Sampaio, J. (2012). A review on the effects of soccer small-sided games. Journal of Human Kinetics, 33(1), 103113.https://doi.org/10.2478/v10078-012-0049-x

Arikunto, S. 2013. Prosedur Penelitian Suatu Pendekatan Praktek. Jakarta: Rieneka Cipta.

Capranica, L., Tessitore, A., Guidetti, L. and Figura, F. (2001) Heart rate and match analysis in pre-pubescent soccer players. Journal of Sports Sciences 19, 379-384.

Dellal, A., Chamari, K., Lee Owen, A., Wong, D. P., Lago-Penas, C., \& HillHaas, S. (2011). Influence of technical instructions on the physiological and physical demands of small-sided soccer games. European Journal of Sport Science, 11(5), 341-346. https://doi.org/10.1080/17461391.2010 .521584

Duarte, R., Batalha, N., Folgado, H \& Sampaio, J. (2009). Effects of Exercise Duration and Number of Players in Heart Rate Responses and Technical Skills During Futsal

Gonçalves, B., Marcelino, R., Torres-Ronda, L., Torrents, C \& Sampaio, J. (2016). Effects of Emphasising Opposition and Cooperation on Collective Movement Behaviour During Football Small-Sided Games. Journal of Sports Sciences, http://dx.doi.org/10.1080/02640414.2016.1143111

Hadi, F. S., Hariyanto, E., \& Amiq, F. (2004). Pengaruh Latihan Ladder Drills Terhadap Peningkatan Kelincahan Siswa U-17 Di Persatuan.

Halouani, J., Chtourou, H., Dellal, A., Chaouachi A \& Chamari K. (2014). Physiological Responses According to Rules Changes During 3 vs. 3 Small-Sided Games in Youth Soccer Players: Stop-Ball vs. Small-Goals Rules. Journal of Sports Sciences, doi: 10.1080/02640414.2014.899707 
Irawan, A. (1996). Senam Aerobik. Jakarta: Pustaka Setia

Iztok Kavcic dkk. (2012). Comparative study of measured and predicted vo2max during a multi-stage Fitness test with junior soccer players. Comparative study of measured and predicted.Kinesiology (2012).

Jamil, R. (1998). Kebugaran Jasmani. Jakarta: PT Gramedia

Owen, A., Twist C dan Ford, P. (2004). Small-Sided Games: The Physiological and Technical Effect of Altering Pitch Size and Player Number. Insight-Issue 2, Volume 7.

Rapids, M, F. 2010. Spring 2010 Academy Guide Book Montana: Spring Soccer Academy. http://flatheadrapids.com/Academy\%20Guide\%20Book.pdf. Diunduh 02 Februari 2012.

Sugiyono. 2013. Metode penelitian pendidikan pendekatan, kuantitatif, kualitatif, dan R\&D. Bandung: Alfabeta.

Sugiyono. 2015. Metode penelitian pendidikan pendekatan, kuantitatif, kualitatif, dan R\&D. Bandung: Alfabeta.

Sukadiyanto dan Muluk, Dangsina. 2011. Pengantar Teori Dan Metodologi Melatih Fisik. Bandung: CV. Lubuk Agung.

Sukardi. (2015). Evaluasi Pendidikan. Jakarta: Bumi Aksara.

Vilar, L., Duarte, R., Silva, P., Chow J. Y \& Davids, K. (2014). The Influence of Pitch Dimensions on Performance During Small-Sided and Conditioned Soccer Games. Journal of Sports Sciences, 32(19), 1751-1759. doi: 10.1080/02640414.2014.918640

Wisesa.D.A. 2013. Pengaruh Latihan Small Side Game 4 VS 4 dan 6 VS 6 terhadap Peningkatan Kemampuan Aerobik Tim Sepakbola UKM UNY. Skripsi tidak diterbitkan. Yogyakarta: FIK UNY

Yiannaki, C., Carling, C \& Collins D. (2018). Futsal as A Potential Talent Development Modality for Soccer-A Quantitative Assessment of High-Level Soccer Coach and Player Perceptions, Science and Medicine in Football, https://doi.org/10.1080/24733938.2018.1483079

\section{Copyright holder:}

(C)(2021) Ribut Wahidi, Intan Aprilia Utami, Oman Hadiana, Firman Adityatama

First publication right:

Indonesian Journal of Sport Management

This article is licensed under:

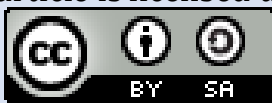

